\title{
The Organization of Care Work in Italy: Gender and Migrant Labor in the New Economy
}

Dawn Lyon

University of Essex

Follow this and additional works at: https://www.repository.law.indiana.edu/ijgls

Part of the European Law Commons, Immigration Law Commons, and the Law and Economics Commons

\section{Recommended Citation}

Lyon, Dawn (2006) "The Organization of Care Work in Italy: Gender and Migrant Labor in the New Economy," Indiana Journal of Global Legal Studies: Vol. 13 : Iss. 1 , Article 7.

Available at: https://www.repository.law.indiana.edu/ijgls/vol13/iss1/7

This Symposium is brought to you for free and open access by the Law School Journals at Digital Repository @ Maurer Law. It has been accepted for inclusion in Indiana Journal of Global Legal Studies by an authorized editor of Digital Repository @ Maurer Law. For more information, please contact rvaughan@indiana.edu. 


\title{
The Organization of Care Work in Italy: Gender and Migrant Labor in the New Economy
}

\author{
DAwN LyON*
}

\begin{abstract}
This article discusses social, political, and economic aspects-particularly, gender and race-based implications-of the organization of elder care work in Italy and globally. Care work for the elderly is a particularly acute concern in Italy and across Europe, as the population is aging while women (the traditional caregivers) have joined the labor force in record numbers and family size has decreased. As the supply of informal female carers has decreased, the need for elder care is increasing. In Italy, a significant trend is the employment of migrant female workers (many from Latin American, Eastern European, and African nations) for home-based elder care, a development supported by institutional, political, cultural-social, and economic contexts within the country. This article emphasizes that the shift to a "migrant-minder" model, however, remains embedded in the ideal of family care for the elderly. Moreover, the trend does not challenge traditional gendered notions of the division of labor between men and women. However, the shift to migrant carers creates new racialand class-based divisions between Italian (or other European) women and the women who serve as migrant carers. Stereotypes based on the characteristics of migrant women (for example, their acceptance of low wages and willingness to work without protest) are used to devalue their care labor as "real" work, as was previously the case for female carers more generally. The gendered and racial implications of this new paradigm of care should be carefully considered as the trend toward migrant caregiving in richer countries continues.
\end{abstract}

\section{INTRODUCTION}

This article is concerned with the organization of care in the global economy. Most work on globalization focuses on money, markets, labor, mobility, and the distribution of resources. However, a key dimension, which arguably underpins

* Senior Research Officer, Department of Sociology, University of Essex, United Kingdom. I would like to thank the Italian scholars who have generously helped me in this research, especially Francesca Bettio and Giovanni Lamura. 
these others, is the activity of care and its organization on a global scale. Arlie Hochschild makes sense of this in terms of what she calls "global care chains," which are "a series of personal links between people across the globe based on the paid or unpaid work of caring." For instance, an older daughter from a poor family looks after her siblings, while her mother cares for the children of a migrating nanny, who in turn cares for the children of a relatively rich family in another country in which both parents are professionals. The needs of professionals in global cities are at the center of these arrangements, which ease their household work. ${ }^{2}$ This has produced a new "ecology of care," 3 in which one kind of care is dependent on another in a series of international interconnections.

This article considers one link in this global chain: the use of migrant workers for elder care in Italy. The article foregrounds the global politics of elder care, distinguishing it from the dominant focus on childcare. The global politics of labor this implies is pertinent to other countries of the region (particularly Greece, Portugal, and Spain) that share similar patterns of care arrangements. In addition, changes in the organization of care work in recent decades can be used to address questions about the transformations of work. This research is part of a broader research program, which explores the transformation of careamong other forms of work-in Europe in recent decades. ${ }^{4}$ The general aim is to analyze the overlaps and intersections between work activities of different kinds and of work activities that are interconnected, despite being undertaken in differing socioeconomic forms and spaces in the contemporary global economy. Within this program of research, care work is taken as a key research site through which to examine differing dimensions of interconnectedness of work activities because it is a site of significant change and one with a global reach over the last decades.

This article argues that migrant labor is used to sustain the continuity of informal family care as an ideal and a practice. Among other things, this has im-

1. Arlie Russell Hochschild, Global Care Chains and Emotional Surplus Value, in ON THE EdGE, Living with Global Capitalism 131 (Will Hutton \& Anthony Giddens eds., 2000).

2. Rhacel Salazar Parrenas, Servants of Globalization: Women, Migration and Domestic Work 69 (2001).

3. Hochschild, supra note 1.

4. This research, "Transformations of Work: New Frontiers, Shifting Boundaries, Changing Temporalities" is supported by an ESRC Professorial Fellowship awarded to Miriam Glucksmann for three years (Jan. 2004-Dec. 2006). The other research probes of the program are: food preparation and distribution; processes of production, distribution, and consumption around callcenters; and consumption "work" associated with food. 
plications for the recognition of the labor of care as work that is itself imbued with gender and race. This article addresses the following questions: How is care work carried out in Italy, in relation to dimensions of formal and informal, paid and unpaid, market and nonmarket work? What is the place of migrant labor within these forms? What is the significance of migrants engaged in care work? After a brief discussion of the conceptualization of care, which sets out some of the issues at stake in researching care, this article outlines the range of socioeconomic modes of provision of care in Italy in comparative perspective. It then focuses on the use of migrant labor for elder care work and spells out the underpinning issues and interconnections. Overall, this article makes a contribution to debates on care, especially the social organization and relations of care, and highlights the interconnections between different forms of provision. While based on Italy, the discussion is also relevant to other industrialized countries, notably in southern Europe. Furthermore, this article also uses the field of care work to raise questions about the politics of this kind of labor and its organization globally.

\section{Conceptualizing and Researching Care}

Care is not a straightforward term to pin down, and the characteristics of caring have been variously explored in feminist scholarship, welfare states research, and public and social policy. ${ }^{5}$ If, very broadly, care refers to the activity of looking after people who are not able to look after themselves, ${ }^{6}$ it has been understood as labor and as love, ${ }^{7}$ as duty and as obligation, ${ }^{8}$ and as a moral orienta-

5. Interestingly, "care work" does not feature in the most recent dictionary of sociology. See A Dictionary of Sociolocy 53 (John Scott \& Gordon Marshall eds., 3d ed. 2005), available at http:// www.oxfordreference.com/views/BOOK_SEARCH.html ? book $=t 88 \&$ subject $=s 20$. The only related term included is "informal care," described as "[c]are given to dependent persons, such as the sick and elderly, outside the framework of organized, paid, professional work." Id. at 308, available at http:/www.oxfordreference.com/views/ENTRY.html? entry=t88.e $1111 \& \mathrm{srn}=1 \& s s i d=$ 443947768\#FIRSTHIT. This definition effectively sustains a strong distinction between different socioeconomic modes of work and hints at the continued invisibility of care.

6. Mary Daly, Care as a Good for Social Policy, 31 J. Soc. PoL'y 251, 252 (2002).

7. Hilary Graham, The Concept of Caring in Feminist Research: The Case of Domestic Service, 25 Sociologr 61 (1991).

8. See Hazel Qureshi, Obligations and Support Within Families, in The New Generational Contract: Intergenerational Relations, Old Age and Welfare 100 (Alan Walker ed., 1996). 
tion, ${ }^{9}$ a way of being in the world. For some, the emotional dimension of the activity is foregrounded: "Care is the activity of attending to others and responding to their emotions and needs." ${ }^{10}$ For others, work is more prominent, as is reflected in various terms, for instance "care-giving work," "people-centred work,"'2 and "care work." ${ }^{13}$ While early sociological and feminist interest in care was concerned with claiming care as work and making this work visible, scholars working within the field of care, largely within social policy, are no longer keen to limit care in this way. ${ }^{1+}$

In recent work, scholars have challenged any strong distinction between "cared" and "cared for," as, through reciprocity and interdependence, we have all experienced the giving and receiving of care at one time or another. The tendency in much work on care has been to constitute some actors as having responsibilities to care, while others as paid to take on the activity of care work. This, it is argued, is misplaced. Starting from the mutual interdependence of care relationships is a positive recognition of the vulnerability of the human condition, including the acknowledgement that some people are constituted as more or less vulnerable at different times and places. ${ }^{15}$ However, this position may overlook the extent to which the scope and possibility of caring and being cared for are differentiated along many social dimensions and how the labor of caring itself is strongly marked by gender, class, and in recent decades, by ethnicity and nationality. Paradoxically, a feminist-inspired critique of the relations of caring runs the risk of obscuring the importance of gender inequalities in care practices. Susan Williams comments that this happens in two ways: first, through the tendency to reify the need for care by describing it in ways that make it seem biologically driven, and thus obscuring policies and structures through which certain

9. See Joan C. Tronto, Moral Boundaries: A Political Argument for an Ethic of Care (1993).

10. Scott Coltrane \& Justin Galt, The History of Men's Caring, in Care Work: Gender, Class, and the Welfare State 15, 16 (Madonna Harrington Meyer ed., 2000).

11. Kari Warness, Caring as Women's Work in the Welfare State, in Patriarchy in a Welfare SoCIETY 67, 67 (Harriet Holter ed., 1984).

12. Carol Thomas, De-Constructing Concepts of Care, 27 Sociolocy 649, 665 (1993).

13. See Care Work: Gender, Class, and the Welfare State, supra note 10.

14. See, e.g., Gender and Caring: Work and Welfare in Britain and Scandinavia (Clare Ungerson ed., 1990).

15. Fiona Williams, In and Beyond New Labour: Towards a New Political Ethics of Care, 21 CRITICal Soc. Pol'y 467 (2001). Cf. Martha Nussbaum, Disabled Lives: Who Cares?, N.Y. Rev. Books, Jan. 11, 2001, at 34; Janet Fink, Questions of Care, in Care: Personal Lives and Social Policy 1 , 14-15 (Janet Fink ed., 2004). 
needs are made evident; and, second, through the claim that care is universal and reciprocal. ${ }^{16}$ While this approach to understanding care is valuable for its aim to unpack ideals and assumptions of autonomy, dependency and the labor of care are not equally distributed.

In the present research, our starting point is that care is work, whether it is recognized as such by individuals or institutions and whether it is paid or unpaid, physical or emotional. ${ }^{17}$ One of the problems within policy debates on care is that issues of social exclusion, quality of life, autonomy, and dependence of those in need of care have been thought of in terms of interpersonal relations and responsibilities. ${ }^{18}$ Care is not only a feature of personal relations between "cared for" and "carer," but is a relational process that has an existence and a set of consequences at the macro level. The relations of caring, the social organization of the work of care, and resources and entitlements all arise through social and economic choices and cultural and political practices and must be investigated as such.

The research presented here is based on various literature, data, and information. First, we reviewed existing published literature in the fields of care, work, and migration in Italy and across Europe, in light of our research aims and questions. Second, statistical data collection focused on the presence and social characteristics of migrant carers and the provision of care in other forms. Third, we conducted primary research through interviews with experts and informants who were either scholars in the field of elder care or public officials engaged in the practical organization of care for the elderly. This fieldwork also included gathering unpublished documents and materials (e.g., local authority reports on care work). ${ }^{19}$

16. Susan Williams, Walter W. Foskett Professor of Law, Indiana University School of LawBloomington, Remarks at the 13th Annual Conference of the Indiana Journal of Global Legal Studies: Globalization and the New Politics of Labor, Indiana University School of LawBloomington (Feb. 12, 2005).

17. See Miriam Glucksmann, Developing an Economic Sociology of Care and Rights, in Rights: Sociological Perspectives (Lydia Morris ed., forthcoming Apr. 2006).

18. See Daly, supra note 6, at 263.

19. Interviews were conducted in central and northern Italy between April and June 2005 by the author and in the Netherlands in April 2005 by Miriam Glucksmann, director of the research program. The questions sought to elicit general understandings of the present and future situation regarding care in Italy (e.g., is there a crisis of care?); the perceived relative contribution of the state, the voluntary sector, the private sector, and the family in the organization of care; meanings of care and of work; and discussions of the composition and conditions of the care workforce in several respects-how it is gendered and racialized, and work that is formal or informal, legal or illegal, paid or unpaid. Further fieldwork is planned in the United Kingdom and Sweden. 


\section{Socioeconomic Modes of Provision of Elder Care: Italy in Comparative Perspective}

In the context of an aging population across Europe and a changing balance between young and old, the need for elder care is stretched and likely to grow as the population ages-this is what Hochschild has termed a "care drain." ${ }^{20}$ In Italy, this problem is already acute as one-quarter ( 25 percent) of the population is currently over sixty. ${ }^{21}$ While increased life expectancy is accompanied by prolonged good health, there is nevertheless a rise in the numbers of the very elderly with significant care needs, and this is set to grow further in the next decades. Indeed, 3.9 percent of the population is over eighty, a proportion that is expected to double by $2010 .^{22}$ More women than men survive into very old age, ${ }^{23}$ many of whom live in single-person households. ${ }^{24}$ The postwar period has also been marked by the lengthening of working life; the demise of extended family in close geographical proximity; and a decrease in family size in the twentieth century and, therefore, in the number of daughters available to care for elderly parents. At the same time, the increase in women's participation in the labor market has been very significant: while the proportion of Italian women in the labor market remains under 50 percent, this represents a twofold increase in the second half of the twentieth century, and labor market participation is far greater among younger than older women. ${ }^{25}$ Taking these factors together, the already

20. Arlie Hochschild, Love and Gold, in Global Woman: Nannies, Maids, and Sex Workers in the New Economy 15, 17 (Barbara Ehrenreich \& Arlie Russell Hochschild eds., 2002).

21. E.g., United Nations, Dept. of Econ. \& Soc. Affairs, Population Div., Population AgeING (2002), available at http://www.un.org/esa/population/publications/ageing/Graph.pdf.

22. Eur. Commission, European Social Statistics, Demography (2d ed. 2002); Eur. commission, Living Conditions in Europe: Statistical Pocketbook (2003), available at http://epp. eurostat.cec.eu.int/cache/ITY_OFFPUB/KS-53-03-831/EN/KS-53-03-831-EN.PDF.

23. In a large province of central Italy in which fieldwork was conducted and which has an especially large elderly population, around 3 in 5 of the over 65 s are women (58.9\% in 2001). One fifth $(21.4 \%)$ of this male population are very elderly-over 80 -compared to nearly 3 in 10 women $(29.5 \%)$.

24. In 1999, $12.4 \%$ of men and $37.1 \%$ of women over 65 lived alone. Barbara da Roit, Welfare Systems, Welfare Packaging and Coping Strategies of Social Risks: The Case of Elderly Dependence in Comparative Perspective 207 figs.4.4 \& 4.5 (2004) (unpublished Ph.D. dissertation, Universitá di Milano-Bicocca).

25. The proportion of women in the formal labor market in Italy remains the lowest in the EU, at $45.2 \%$ in 2004. Eur. Commission, Employment Rate: Females, http//europa.eu.int/comm/ index_en.htm (follow "Statistics" hyperlink under "Quicklinks" in the bottom-right of the page; then click circle "EN" (language) image hyperlink; then follow "Employment" hyperlink under 
evident demographic issues of an aging population and a reduction in the supply of informal female carers are likely to peak in the next twenty years.

If care was once assumed to be performed within families in a relatively uncontested way, it is now the subject of considerable debate within social policy and politics more broadly, and it is an area in which we can see major shifts in work arrangements, including the creation of new occupations, agencies, and other organizations. The issue of how to manage care has moved in different directions with different outcomes, in principle and practice, across Europe and elsewhere. Care provided by women motivated by affection or obligation (arising from their locations within households) is strong in Italy and Spain, as is care provided through the employment of migrant men and women (arising from their location in the global economy); state provision of services dominates in Sweden where residential facilities and home services are widely used; and voluntary work is significant in the provision of care in the Netherlands. While family care remains the primary form of elder care across Europe, over the last decades care has in some places moved outside of the realm of affective relationships rooted in traditional kinship relations and into other forms of provision, supplementing, if not always substituting, family care. This process of defamilialization of care means that it has become commodified-managed in its component parts, which are assigned a financial and temporal value in the market. In other words, the time of a care worker is costed and the labor of care is timed. ${ }^{26}$

Italy has witnessed some of these trends toward commodification, yet the provision of care remains characterized by an "explicit familialism" ${ }^{27}$ in policy, as options other than informal family care by women are not easily available. This emphasis on family care is reflected in images and ideals that are present in

\footnotetext{
"Structural indicators" in bottom-middle of page; then click on the "Table and Graph" icon to the left of "Employment rate: females" under "Employment"). Most of these women are employed full-time.

26. See generally, e.g., Gøsta Esping-Andersen, The Three Worlds of Welfare Capitalism 35-47 (1990).

27. Sigrid Leitner, Varieties of Familialism: The Caring Function of the Family in Comparative Perspective, 5 Eur. Societies 353, 358-59, 362-65 (2003). Explicit familialism refers to the organization of welfare in such a way that it relies on and actively supports the family as the main source of care provision, as opposed to relieving the family of caring responsibilities through state provision, for instance. Id. at 357 .
} 
private accounts and public discourses..$^{28}$ Additionally, family care is an orienting principle of social policies and practices in the organization of care, for instance, in direct cash payments to the family to support elder care and in the low usage of residential facilities. Table 1, opposite, summarizes the main modes of provision of social care in Italy. The table can be read as setting out the forms of provision from the most informal-assistance from family - to the most formalstate and private sector provision. While it is useful to describe these different forms of provision, in practice there are many interconnections and variations within and between these forms, for example, local authority support of voluntary organizations or direct payment by the state to family members for care.

The institutional relationships between different types of care-social care, health care, and pedagogic care-have implications for the organization and costs of provision. While these categories are not operationalized in uniform ways, social care is usually distinct from medical care, therefore referring to nonmedical care needs, and both social and health care are distinct from educational dimensions of care work, the latter being most relevant to childcare or care for those with learning disabilities. In Italy, social care is demarcated from medical care. Health care (access to general practitioners and acute hospital care) is free; means-tested social care (in the form of services) is available through local authorities; cash payments are made from the state (means-tested disability allowances and non-means-tested attendance allowances); and local authorities may provide additional, usually means-tested, financial assistance. Long-term residential and nursing home costs are only partially covered by the state, making the distinction between health and social care especially significant, as in England and elsewhere. Conspicuously, enrollment in residential homes in Italy is very low, although there is considerable regional variation with much higher usage in the North than in the South. Only around 2 percent of elderly people in Italy live in residential homes, a figure that is between one-third and one-half that of other industrialized countries. ${ }^{29}$ This low enrollment is in contrast to

28. See Arlie Russell Hochschild, The Culture of Politic: Traditional, Postmodern, Cold-Modern, and Warm-Modern Ideals of Care, 2 Soc. PoL. 331 (1995) (identifying four ideal types of images of care for the U.S.: traditional, post-modern, cold-modern, and warm-modern, each of which is a response to the care deficit, asking different questions and placing a different value on care).

29. Francesca Polverini et al., EUROFAMCARE, National Background Report for Italy, in Services for Supporting Family Carers of Elderly People in Europe: Characteristics, CoverAGE, AND USAGE (2004), at http://www.uke.uni-hamburg.de/extern/eurofamcare/documents/ nabare_italy_rcl_a5.pdf. In Germany, Japan, the United Kingdom, and the United States, the 
Table 1: Modes of Provision of Social Care in Italy

\begin{tabular}{|c|c|c|}
\hline \multirow[t]{4}{*}{ Informal } & $\begin{array}{l}\text { Family } \\
\text { (and friends and } \\
\text { neighbors) }\end{array}$ & $\begin{array}{l}\text { - co-resident (usually spouse, most often elderly wife) performing } \\
\text { both personal care and household activities } \\
\text { - nonresident primary carer (usually daughter or son in close geo- } \\
\text { graphical proximity or other female relative in } 45-64 \text { age group) } \\
\text { - supplementary care where primary care is provided in another } \\
\text { mode, e.g., substituting paid care worker on days off } \\
\text { - management of care, e.g., employment of carer, relationships with } \\
\text { public service providers and/or public/private institutions }\end{array}$ \\
\hline & Voluntary sector & $\begin{array}{l}\text { - religious or co-operative residential homes } \\
\text { - religious/charity based support agencies and networks } \\
\text { - voluntary sector services, e.g., shopping or transport, often orga- } \\
\text { nized in collaboration with local authority } \\
\text { - voluntary sector projects submitted to local authority for financing } \\
\text { - trade-union-based networks of solidarity }\end{array}$ \\
\hline & $\begin{array}{l}\text { Public-private } \\
\text {-family nexus }\end{array}$ & $\begin{array}{l}\text { - home-based (migrant) carers (some co-resident)—can be hired } \\
\text { through local authority lists of registered carers or privately } \\
\text { through agencies, personal contacts, etc. }\end{array}$ \\
\hline & State ${ }^{2}$ & $\begin{array}{l}\text { - residential homes; day centers; holiday centers } \\
\text { - home-help: personal care and hygiene, e.g., bathing, hairdressing, } \\
\text { pedicures; housework/cleaning } \\
\text { - home meals } \\
\text { - telephone assistance/alarm buttons/video conferencing, etc. } \\
\text { - specialized services, e.g., for Alzheimer's patients and their families } \\
\text { Cash payments include: care allowance (paid to elderly person), } \\
\text { attendance allowance (paid to family), and disability pension }\end{array}$ \\
\hline Formal & $\begin{array}{l}\text { Market (private } \\
\text { for-profit firms) }\end{array}$ & $\begin{array}{l}\text { - residential homes } \\
\text { - other services similar to those offered through public sector }\end{array}$ \\
\hline
\end{tabular}

\section{Notes}

1. According to expert interviewees, about $60 \%$ of the retired population are union members, and many are actively involved in networks and services.

2. This part of the list is developed with reference to documents from a large central Italian province in which fieldwork was conducted. While these are indicative, there is considerable national variation. Additional services include: temporary services, e.g., Summer help; and preventive measures, e.g., installation of air conditioning.

3. The "care allowance" is administered through local authorities to elderly people at risk of insitutionalization. Attendance allowance (assegno di accompagnamento) is paid by local authorities (municipal level) to the family of the recipient of care. The amount varies considerably, depending on income and support needs, from less than 100 euros per month to 450 euros per month if a private assistant is hired to whom it is paid directly (if assistance is formally declared). Disability pension (233 euros per month, but 252 euros in case of full blindness) is means-tested, and paid by the State to the elderly; attendance allowance ( 430 euros, but 670 euros in case of blindness) is non-means-tested, and paid by the State to fully disabled elderly only; care allowance (amount varies) is usually means-tested, and is paid by some (but not all) local authorities (Municipalities or Regions) to (usually) only fully disabled elderly or their family caregivers (and in a few cases also to non relatives). See Francesca Polverini et al., EUROFAMCARE, National Background Report for Italy, in Services for Supporting Family Carers of Elderly People in Europe: Characteristics, Coverage, and Usage (2004), at http//www.uke.uni-hamburg.de/extern/eurofamcare/documents/nabare_italy_rc1_a5.pdf. 
projections of twenty years ago, when it was imagined that a rising elderly population would lead to increased use of residential homes. The cost of residential facilities is high: the simplest level, casa di riposo (residential care home), typically costs around 1,100-1,200 euros per month, while the cost of a nursing home is upward of 2,000 euros per month. ${ }^{30}$ In instances where the costs have been lowered or local authority cash contributions increased, applications have increased very significantly. ${ }^{31}$

In research conducted on the provision of care, in which EU countries were ranked on the basis of the informal care provided by women, Italy-along with Greece, Spain, and Portugal-fell within the group of countries described as "uneven providers." These countries overprotect some segments of the population and underprotect others and, notably for the present research, provide the lowest institutional or state-supported home-based care. ${ }^{32}$ In Italy, in addition to the low proportion of the elderly population in residential care, home-based services are also very limited. ${ }^{33}$ In general, social services do not have the resources to satisfy care needs beyond a very limited number of cases or situations. It is family care that predominates; it is a social and practical obligation. Estimates indicate that 11 percent of the population over fifty (close to 2.5 million people) care for a dependent older relative, and that the majority of these carers are women. ${ }^{34}$ Indeed, the enduring gendered division of unpaid care work is conspicuous across European countries. Other figures suggest that long-term care needs are met by family and friends in

proportion is 5\%; in Canada, 6\%; in Australia, Belgium, and France, 6.5\%; and in Sweden, 9\%. Id. at $47 \mathrm{n} .12$. Recent figures for a large province in central Italy suggest that around $1.6 \%$ of the over $65 \mathrm{~s}$ are in residential facilities; two-thirds of these are nursing homes.

30. These figures come from expert interviews.

31. Da Roit, supra note 24.

32. But see Francesca Betrio \& Sacha Prechal, Care in Europe, Joint Report of the "Gender and Employment" and the "Gender and Law" Groups of Experts 34 (1998) (suggesting there may be more supports in practice than appear on the basis of policies, e.g., respite hospitalization in Italy in the 1990s).

33. See Franco Pesaresi \& Cristiano Gori, L'assistenza agli anziani non autosufficienti in Europa, in Anziani e sistemi di welfare 75 tbl. 11 (Carla Facchini ed., 2005) (estimates are as low as 3\%). Cf. Francesca Bettio \& Janneke Plantenga, Comparing Care Regimes in Europe, Feminist Econ., Mar. 2004 , at 85,98 (pointing out a correlation between good state providers of institutional care and home based services).

34. Polverini et AL., supra note 29, at 12-14. See also Bettio \& Plantenga, supra note 36, at 103 fig.7 (calculating that $37 \%$ of women aged $25-49$ are not active in the formal labor market because of care responsibilities). 
83 percent of cases, ${ }^{35}$ and a large proportion of persons offering informal care to adult dependent family members do so without any other form of support. ${ }^{36}$

Notwithstanding this picture, there are a variety of configurations of care and new forms that have emerged in recent years. The modes of provision do not usually exist in isolation from one another; for instance, delivery of care services by private and voluntary sectors is both part of and in addition to public provision, resulting, for instance, in public-private-voluntary hybrids. ${ }^{37}$ Furthermore, the separation often assumed in policy between formal care by professionals in institutions and informal care at home by family and friends may have little basis in practice. ${ }^{38}$ So, while family care remains the dominant form of care in Italy, there are novel mixes of forms of care that transcend the public-private, market-nonmarket, and paid-unpaid distinctions. In the next section, this article focuses on the use of migrant labor for elder care work and explores its relationships to other forms of care in a global perspective.

\section{The Use of Migrant Labor for Elder Care Work in Italy}

If family care remains the dominant mode of provision of elder care, a very significant trend in recent years is the employment of migrant labor for homebased care, both as resident and nonresident care workers. There are a large number of domestic and personal care workers in Italy, as compared to countries of north and west Europe. Most are migrant women who are often employed without a regular contract. ${ }^{39}$ While this phenomenon-often referred to as badantehas been visible in the past decade or so, it has a longer history. ${ }^{40}$ In the 1970 s,

35. Francesca Bettio et al., The "Care Drain" in the Mediterranean: Notes on the Italian Experience 4 (2005) (unpublished manuscript, on file with the author), available at http://www. gu.edu.au/school/gbs/irl/working_party/Papers/Simonazzi.pdf.

36. I am grateful to Manuela Naldini for bringing this to my attention.

37. See Glucksmann, supra note 17.

38. See Fink, supra note 15 , at 33 . It is widely reported that family members routinely perform basic personal care for relatives in residential facilities, such as taking in food and washing and dressing patients. This is also the case in hospitals where relatives wash or feed patients, stay overnight with them, or, in an interesting twist, pay someone else to do so.

39. The regularization schemes make visible workers who were previously without legal status. Bettio et al, supra note 38 .

40. The term badante refers to a person who cares for another elderly or disabled person. It is a bureaucratic term which has also appeared in legal texts, and an everyday description. Accademia della Cursca, New Words, http:/www.accademiadellacrusca.it/parole/parola_singola.php? id = 779 \&ctg_id=58. For the history of domestic service in Italy, see generally JACQueline ANDALL, Gender, Migration and Domestic Service: The Politics of Black Women in Italy (2000). 
women migrants employed as domestic workers or carers were from the former Italian colonies of Somalia, Ethiopia, and Eritrea, or from Cape Verde or the Philippines. While employed as domestic helpers, and less so as care workers, Filipina women were mainly middle class, educated, and possessed good qualifications. From the 1980s, single women, also with medium levels of education, arrived in Italy from Peru, El Salvador, the Dominican Republic, Colombia, Chile, Brazil, and Argentina. Through the 1990s, single female migrants originated from central and eastern Europe, including Poland, Romania, Hungary, Russia, and Albania. ${ }^{41}$ For those employed in the formal sector, numbers are regulated by an annually fixed quota, and permits are strictly tied to employment. This makes domestic workers highly dependent on the goodwill of their employers and often subject to exploitation by them. Alongside formal employment, large numbers of women are employed informally. For instance, women from Eastern Europe often work on a temporary basis, for two to three months at a time, sharing jobs with female family members or friends. This practice, widely referred to as "pendulum migration," means that migrants rotate work in Italy, and other EU countries, with periods at "home," repeatedly returning on tourist visas.

Recent estimates suggest there are 600,000-700,000 people, most of whom are foreign migrants, engaged in home-help care as personal assistants hired by Italian families. ${ }^{42}$ Women represent the majority of carers, although some evidence suggests that the proportion of migrant men is also increasing. Presently, figures are available for the country of origin of registered domestic workers, a category that includes care workers but excludes all those employed informally or without legal status. The most up-to-date figures estimate that at the end of 2004 officially about 496,000 domestic workers worked in Italy, of whom 21 percent $(104,000)$ come from the Ukraine, 16.4 percent $(81,000)$ from Romania, 9.5 percent $(48,000)$ from the Philippines, 7.1 percent $(34,000)$ from Poland, 6.4 percent $(31,323)$ from Ecuador, 5.7 percent $(28,000)$ from Moldova, and 5.1 percent $(21,000)$ from Peru. ${ }^{43}$ If we consider the location of migrant workers within Italian households, more than one in ten Italians (10.2 percent) over sixty make use

41. Andall, supra note 43; Giovanna Campani, Donne Immigrate in Italia, in Stranieri in Italia: Cratteri e tendenze dell'immigrazione dai paesi extracomunitari (Giovanni Cocchi ed., 1989); Caritas Romana \& Fondazione Migrantes, Immigrazione: Dossier Statistico 2004: XIV Rapporto (2004).

42. In comparison, the total migrant population is estimated at 2.5 million people. See Polverinı ET AL., supra note 29, at 21 (citing various reports).

43. Caritas Romana \& Fondazione Migrantes, supra note 44. 
of privately employed domestic workers or carers, a figure which rises to 12.4 percent for seventy to seventy-nine year-olds and 20 percent for those over eighty, ${ }^{4+}$ evidencing the significance of migrant carers for the elderly.

The trend toward the employment of migrants for care work has taken place in a specific political, economic, cultural-social, and institutional context. Italy is a relatively weak welfare state with a low supply of private-sector alternatives. At the same time, the underground economy operating outside the scope of legal regulation makes it easy for migrants to live and work in shifting relations of legality and illegality. The retrospective orientation of regularization schemes for those in work but without legal status (there have been five schemes since the 1980s) is considered to have had a powerful impact on migratory practices. ${ }^{45}$ Furthermore, the presence of large numbers of migrants has itself generated change, causing the informal economy to expand and take new directions, notably in the provision of care. ${ }^{46}$ All of this takes place within a set of global socioeconomic and cultural processes and relationships that shape this mobility, ranging from the movement of global capital to the technologies of travel. ${ }^{47}$ The lack of a wider politics of care turns it into a private issue to which individual solutions must be sought.

Of further significance for the development of this form of care is the relatively low cost of employing a migrant worker. If social security payments are made and the situation of the worker is completely regularized, the costs may exceed 1,000 euros per month for nonresidential carers, especially in northern Italy; otherwise, they may be less than 800 euros per month. ${ }^{48}$ In a context of generous pensions and disability allowances, and the payment of attendance allowance of a maximum of 450 euros per month, this is an option that is within the reach of even lower-middle-class families and is considerably more affordable, as well as more appealing, than a residential care home for the elderly relative.

44. Bettio èt al., supra note 38 , at 12.

45. See Giuseppe Sciortino, When Domestic Labour Is Not Native Labour: The Interaction of Immigration Policy and the Welfare Regime in Italy, in Migration in the New Europe: East-West Revisited 177 (Agata Górny \& Paolo Ruspini eds., 2004); Lydia Morris, Managinc Migration: Civic Stratification and Migrants' Rights (2002); Rossana Trifiletti, Restructuring Social Care in Italy, in Gender, Social Care and Welfare State Restructuring in Europe 175 (Jane Lewis ed., 1998).

46. Bettio et al., supra note 38 .

47. See generally Natalia Ribas-Mateos, How Can We Understand Immigration in Southern Europe?, 30 J. Ethnic \& Migration Stud. 1045 (2004).

48. See supra note 19. 
Finally, the regulation of care is uneven. The location of work being a private residence, and its naturalization as a feminine activity, seems to have placed it in a realm beyond ordinary regulation. Very few care workers have any kind of relevant qualification, although quite a number are well qualified in other unrelated fields. As an initiative in one central Italian local authority, a training program has been established to give credentials to the work that 300 registered women carers are doing, although the scheme has, to date, met with very limited uptake. Still, this suggests a shifting reformulation of home-based elder care from an everyday activity with an unelaborated economic relation into care as a field of work.

Thus far, this article has sought to map the ways in which care is performed across the boundaries of work between paid or unpaid, market or nonmarket, and formal or informal in Italy, evidencing in particular the use of migrant labor for elder care and its relationship to other forms of provision. Italy is the "oldest" country in the world in terms of the proportion of elderly persons within the population. ${ }^{49}$ This makes it an interesting case to explore what happens when demand for elder care is so high, especially in a context of the diminishing supply of informal female carers. This, combined with limited alternatives in public or private provision, a significant informal economy, and regularization schemes for migrants, has given rise to the appeal of migrant labor for elder care work. It is a relatively affordable option and is effectively supported by government through cash payments for care. Crucially, this can only happen in a context of uneven development globally, which makes such work financially attractive to migrants, in spite of its low pay by EU standards. ${ }^{50}$ Within Italy, alternatives might have arisen, and there are indeed some reports that residential facilities were expected to fill an anticipated gap in supply. ${ }^{51}$ What is significant is that, in addition to cost, migrant labor is appealing insofar as it allows a sustained emphasis on familialism and the continuity of family care. In short, migrant labor fills a supply gap at a low cost and sustains an ideal. The next section discusses the national and global implications of these arrangements.

49. See United Nations, supra note 21.

50. In practice, the money often goes less far than is imagined, and the women end up working for far longer periods than anticipated.

51. See supra note 19. 


\section{Implications: Gender and Race in the Meaning and Practice of Care Work}

In this section, the discussion explores what the care work arrangements presented above mean in terms of the politics of these forms of labor, the construction of the workers themselves, and the labor they perform.

In Italy, migrant labor has partially replaced and partially coexists alongside two other forms of labor: first, unpaid care work done by women in their own homes, and, second, the paid care work of former rural Italian migrants to urban centers. If higher-class Italian families have long used paid care within the home for the elderly and for children, as well as for domestic work more generally, what is new about the present arrangements is their reach, whereby a broader swath of the population can now employ a carer or a domestic worker. This is widely described as a shift from a model of family care to the migrantminder model..$^{52}$ What we draw attention to in this article, however, is the embeddedness of migrant labor for care work within the previously existing forms of provision of care, facilitated by state supports such as cash payments or registers of care assistants and incentives to formally employ migrant women. In particular, we argue that this form of care represents a continuity in the dominance of family care as a practice and an ideal in Italy. The often continuous presence of the paid carer and nonspecification of tasks shares the characteristics of informal care. ${ }^{53}$ At the same time, while some of the actual labor of care has been displaced from wives and daughters, they nevertheless remain significantly responsible for the management of the care contract or relationship. Furthermore, where the labor of one group of women is substituted with that of another, the domestic division of labor between men and women has largely remained unchallenged..$^{54}$

One element that is curious in the care arrangements in Italy is the apparent paradox of a strong normative ideal of personalized care (i.e., the importance of a particular person, for instance, mother or daughter, to act as the carer-what

52. See, e.g., Bettio et al., supra note 38. Some argue that the presence of migrants is crowding out other formal alternatives. This evidences a relationship between forms of care where the existence of one form shapes the development of another in which the closure of residential homes is a case in point.

53. Da Roit, supra note 24 , at 322.

54. Annie Phizacklea, Migration and Globalization: A Feminist Perspective, in The New Migration in Europe: Social Constructions and Social Realities 21 (Khalid Koser \& Helma Lutz eds., 1997). Recent reforms of cash-transfer payments reinforce the male-breadwinner/femalehousekeeper model. 
Elisabetta Addis calls the "person-specificity" of care), on the one hand, and a high use of migrant labor for (elder) care work, on the other, all the while retaining a vocabulary of personalized care. ${ }^{55}$ Family care is both a social duty in Italy and a legally binding financial responsibility, the two dimensions being traditionally addressed through intergenerational support. ${ }^{56}$ While the migrant minder-carer may be present in the family or home, there is very limited discussion of the (initial) emotional dis-connection between carer and recipient of care, as compared to the long-standing bonds of family members, yet there are commonplace references, in qualitative research on the employment of migrant carers, to the migrant carer as "one of the family." While this may be read as the formation of some genuine bonds of affection (albeit in an unequal power relation), it can also be interpreted, in the Italian context, as an appropriation into the family in order to sustain the ideal of family care.

Furthermore, the employment of migrant women in care work has produced new divisions between women. While class retains its salience, there are distinctions between Italian, or west European, and "other" women. ${ }^{57}$ These distinctions are reflected in caring work itself, where native Italian workers dominate the more professionalized fields of paramedic care, while migrant workers perform a larger share of the labor associated with the "dirt" of the body. Moreover, within the understanding of "other" there are subtle distinctions in public discourses and everyday accounts between workers of different nationalities.

Women have traditionally been thought of as having an innate capacity for caring. Even though biological and essentialist accounts have been debunked, the persistent narratives which echo these orientations, coupled with everyday experiences that emphasize women's caring responsibilities, continue to construct women as carers. In addition to this gendered construction of caring, we now find evidence that care is racialized. In a recent study of women migrants from Bulgaria and Hungary in Italy and the Netherlands, interviews with native women expose some of the characterizations of migrant women working in the field of care as "naturally" gifted for such a role and generally charitable in disposition, all

55. Elisabetta Addis, Gender Symmetry in the Reform of European Welfare States (European Univ. Inst., Robert Schuman Ctr. for Advanced Studies, Working Paper RSC No. 2002/25, 2002).

56. Legal obligations extend to the third degree of kinship. Polverini et al., supra note 29, at 23. Those most targeted are spouses, sons and daughters, and sons- and daughters-in-law. See id.

57. See Helma Lutz, The Limits of European-ness: Immigrant Women in Fortress Europe, FemINist Rev., Autumn 1997, at 93. 
in contrast to their Italian counterparts. ${ }^{58}$ Several interviewees made much of their employees' willingness to labor without complaint and celebrated their apparent subservience as personal (or national) characteristics-rather than, for instance, an indication of their relative powerlessness. The migrant women were applauded for their acceptance of low wages by the native women, who at the same time admonished their Italian counterparts who would demand double for similar work. Furthermore, distinctions were made between different migrant groupings, based on stereotypes that appear to be widespread. For instance, women from some Latin American countries, according to the interviewees, have "sweet" temperaments making them good carers (but not as good cleaners). ${ }^{59}$

This emphasis on the caring characteristics of some migrant women is also used to effectively devalue the labor they perform as work - as was previously done with respect to women more generally. If caring is a dimension of character, it is naturalized and seen as effortless, or as love or nature and not real work. In the case of migrant women employed in the home, it might be that employers find it problematic to fully recognize care as work and at the same time sustain the notion of family care. Indeed, the very presence of the employee within the home, in a space of overlapping spheres of life, confuses more formal contractual relations. The employee is therefore incorporated into the family as a way to conceal the labor relation and to extend the sense of personhood of the employer (especially where the latter is a son or daughter with a sense of responsibility for the care of an elderly parent). In particular, this operates through the conditions of work, such as extra hours and payment. Indeed, care work is often at the interface of relations of affection and/or obligation, work, and financial exchange. ${ }^{60}$

Overall, the labor of migrant carers in personal services is marginalized as unproductive and is not seen as real "work." While feminists have long fought for the recognition of women's unpaid labor in the home as work, the paid labor of migrant women to take on some of these same activities in the homes of Italian and other women citizens is arguably even more strongly excluded from the category of work, not only on the basis of gendered relations but, in addition, through the dimensions of migrancy and legality. ${ }^{61}$ If employers position mi-

58. Women Migrants from East to West: Gender, Mobility and Belonging in Contemporary Europe (Luisa Passerini, Dawn Lyon, Enrica Capussotti \& Ioanna Laliotou eds., forthcoming 2006).

59. These stereotypes are widely reported in other research. See, e.g., Da Roit, supra note 24, at 317.

60. Thomas, supra note 12, at 658 .

61. Laura M. Agustín, A Migrant World of Services, 10 Soc. Pol. 377, 380 (2003). 
grant carers as not engaging in real work, this also sidesteps issues of social justice and avoids a confrontation with the often dissonant reality of highly educated migrant women doing low-paid and low-status work for middle-class families. Finally, the use of migrant labor for care work, and especially the labor of relatively young women, has implications not only within the country in which care is supplied but also for the sending country of the migrant labor: the "care drain" is at the other end of the global care chain from the "care deficit." 62 This shift in labor leaves some countries without either the necessary professionalized care available or a supply of informal carers for their own populations.

\section{Conclusion}

This article has evidenced and discussed the reliance on migrant labor for the care of the elderly in one country of western Europe. While we want to recognize new opportunities and broader life chances that these new jobs in the field of care might open up for some, there are new problems and costs in global care chains. These arrangements produce new inequalities in access to care and to choices about care. ${ }^{63}$ "Opportunities" for migrant women-who might have high levels of education and aspirations for other kinds of work-mean that care work (along with domestic work and sex work) in richer countries becomes an option that is sometimes difficult to refuse when it promises to offer financial support for many family members. These arrangements not only largely sustain gendered associations of caring, but create new racialized distinctions between women. Finally, care arrangements rely on normative assumptions about who should care and how and where that care should take place-in short, dominant ideals of care. Further research is needed, especially from a more comparative perspective, to better understand the appeal of different configurations of care and what might be viable alternatives to the current practices of the displacement of care on a global scale.

62. See Bettio et al., supra note 38 .

63. Hochschild, supra note 1 , at 142. 